\title{
An Empirical Study of Application of Multimodal Approach to Teaching Reading in EFL in Senior High School
}

\author{
https://doi.org/10.3991/ijet.v15i02.11267
}

Xuequan Pan $\left.{ }^{(}\right)$, Zhixin Zhang

Huaibei Normal University, Huaibei, China

xuequanpan@126.com

\begin{abstract}
English reading skill is one of the most important skills for senior high school students who learn English as a foreign language (EFL). However, the present reading teaching in ELF is still teacher-centered which neglects students' learning interest and their participation in the teaching process. In 1990s, scholars proposed the application of multimodal theory which suggests that semiotic resources (sound, images, video, animation, motion, color, facial expressions, etc.) can be used to stimulate different senses of students so as to improve their learning efficiency. The present study is intended to apply multimodal approach to reading teaching in EFL in senior high school and tries to find out whether the multimodal teaching can motivate students' participation in English reading class and improve their reading proficiency, and to get to know students' attitude towards multimodal approach. With students of a high school in Anhui in China as the research subjects, an English reading teaching experiment was carried out. The data collected from reading tests and questionnaires indicated that the application of multimodal teaching approach in high school English reading teaching can motivate students' participation in reading class and improve their English reading proficiency, and most students take a positive attitude towards multimodal teaching approach.
\end{abstract}

Keywords-Multimodal approach, application, senior high school, English reading teaching

\section{Introduction}

Human beings communicate information in a variety of ways; language is only one of them [1]. Every day when we read newspapers, magazines, advertisements, posters, story books, textbooks, loose-leaf anthologies, encyclopedias, brochures, computer interfaces, etc., we will inevitably make use of nonverbal form of texts [2]. With the rapid development of multimedia, computer and network technology, non-verbal symbols such as pictures, mind maps, music, flashes, and videos have become an important means of expressing ideas. Non-verbal symbols are independent of and interact with each other, and generate meanings together with linguistic symbols. In a word, a rich diversity of communication channels and media, including language, 
technology, image, color, music, video and other semiotic systems can be used to stimulate human sensory organs in communication. In other words, multimodal means is indispensible in the process of commutating meanings, so in language learning and teaching, multimodal means is a factor that cannot be neglected. Since the beginning of this century, more and more attention has been paid to applying multimodal approach to teaching English as a foreign language. However, many teachers of English in China still stick to the traditional teaching mode which stresses the explanation of language forms. They spend too much time in translating paragraphs, explaining vocabulary and analyzing grammatical structures, but seldom make use of images, charts, video or audio clips to cultivate students' interest in English teaching and motivate students to participate in classroom interaction. In this study the authors apply the multimodal approach to senior high school English reading teaching with the aim to find out whether multimodal reading teaching is beneficial to improving English reading proficiency and motivating students' participation in English reading class activities, and get to know the students' attitude towards multimodal reading teaching.

\section{$2 \quad$ Literature Review}

\subsection{Notions of modality, multimodality, multimodal approach}

Modality: According to Yueguo Gu, modality means the way human sensory organs interact with the outside world [3]. In other words, modality refers to communication channels and media, including language, technology, image, color, music and other semiotic systems which can stimulate different human senses [4]. There are generally five communication modalities: visual modality, auditive modality, tactile modality, olfactory modality and gustatory modality.

Multimodality: In Scollon's opinion, multimodality refers to a variety of modalities that were used in communication, such as language, color, taste, image and so on. In other words, employment of two or more senses for interactions will form multimodality [5]. Multimodality emphasizes the diversity of symbolic application in both oral and written communication; it involves employment of the image, sound, word, color, movement, space, etc. in communication.

Multimodal approach: Multimodal approach in this study means using two and more senses for interactions in language teaching. As a kind of teaching approach, it emphasizes the cultivation of learners' multiple abilities, and advocates the use of network, pictures, role play and other channels to mobilize learners' senses. In the process of multimodal teaching, students can perceive, understand, encode and store the input information which will lay a foundation for the conscious and automatic output of information.

In English teaching class, teachers can make use of graphs, words, colors, picture, movement, audio clips, videos, or tangible objects to present teaching content, give explanation, or organize classroom interaction. In this process different communication channels and semiotic systems are employed to stimulate different senses of stu- 
dents so as to stimulate their interest in learning English, and motivate them to participate in language activities and achieve a better teaching result.

\subsection{Related studies of multimodal English teaching}

Roland Barthes (1977) was the first scholar to put forward multimodal discourse analysis and to discuss the relationship between different modes. He argued that there was an interaction between images and languages when expressing meanings in rhetoric of the image [6]. In 1996, New London Group put forward multiliteracies on the basis of social semiotics. They pointed out that in classroom teaching teachers should make use of teachers' and students' sense organs, modem technology, the Internet, and surroundings to nurture students' multiliteracies [7]. From then on, multimodality came to academic field. Based on previous studies, Stein (2000) introduced multimodal approach into classroom teaching and believed that multimodal teaching can facilitate synergistic communication among one's brain, body, and other sense organs [8]. Royce (2002) analyzed how teachers could apply teaching materials and various modalities to enhancing students' ability of multimodal communication [9].

In China, scholars first explored some hypotheses and principles of multimodal approach in teaching English as a foreign language. Yueguo Gu differentiated between multimedia learning and multimodal learning and believed that the two forms of learning integrate in a variety of ways. He formulated five hypotheses concerning multimedia learning and multimodal learning and concluded with an outline of how to use agent-based modeling language to datamine the multimedia and multimodal interactions for computer simulation [3]. Delu Zhang tried to develop a theoretical framework for multimodal discourse analysis and research with the theory of systemic functional linguistics, and provided guidance for the choice of effective procedures and practice in foreign language teaching under the condition of modern media technology [10].

Empirical studies on application of multimodal teaching approach to teaching English as a foreign language were also carried out by many scholars. Meiwei Sun conducted an experiment of online English teaching in the architecture major by means of a multimodal online English teaching system and found out that Multimodal learning has a good application effect in English teaching in science and engineering, so the author concluded that the multimodal online teaching system design can be applied to online English teaching [11]. Wei Huang conducted an experiment of college English listening teaching in which activities are organized to mobilize the students' visual, auditory, tactile, thinking and other modes to participate in learning; the results indicated that multimodal teaching can improve students listening comprehension ability and their spoken English as well as enhancing their public speech skills and even allround development [12]. Wei Zhang, Xiaobin Liu and Rong Zhou made an empirical study of multimodal theory-oriented courseware application in English grammar courseware teaching; the experiment results showed that English grammar teaching based on multimodality theory has incomparable advantages that traditional English grammar teaching cannot provide. It combines words, image with other audio-visual symbols, guiding students to find out and analyze grammar rules so that they can have 
deep understanding and accurate use of language forms [13]. Meijia Lv and Weijiao $\mathrm{Mu}$ applied the multimodal theory to the teaching practice of college English reading in order to find out the effect of the multimodal teaching on college students' reading ability with non-English majors as the research subjects; the result suggested that this teaching method can strengthen students' ability of the construction of discourse meanings due to the rich input of information and the stimulus of different senses [14].

The previous studies show that by combining words, images, videos with other audio-visual symbols in English teaching process, or through the rich input of information and the stimulus of different senses, multimodal teaching can improve students' English listening, speaking and reading abilities, and help students to have deep understanding of the teaching material and to use English language in communication effectively. However, most empirical studies are devoted to college English teaching; very little attention was given to high school English teaching. As high school English teaching is equally important, the present study is intended to apply multimodal approach to reading teaching in EFL in high school with an aim to find out the effects of its application and students attitude towards multimodal approach.

\section{Methodology}

\subsection{Research questions}

In the present study a teaching experiment of English reading was conducted in a senior high school with the hypothesis that multimodal teaching approach can achieve an ideal effect in English reading teaching. To be specific, the research was carried out to answer the following three questions:

- Will students' English reading proficiency be improved after application of multimodal teaching approach?

- Can multimodal approach motivate students to participate in interaction in English reading class?

- What is the students' attitude towards multimodal reading teaching approach?

\subsection{Research subjects}

The experiment was carried out in Dangshan No. 2 Senior High School in Anhui Province of China. Zhixin Zhang the co-author took part in the teaching experiment as a student teacher. This research took students of Class 2 and Class 3 of Grade 2 as the research subjects. Students in the two classes concerned were 16 years old on the average. A pre-experiment test was given to all the students concerned to make sure there was no significant difference in English reading proficiency between the two classes. Class 2 (with 53 students) was treated as an experimental class, and Class 3 (with 55 students) as the control class. The research experiment began at the beginning of March and ended at the end of April in 2019, lasting two months. The same 
textbook (Student Book 3 of New Senior English for China) was used by all the students of the two classes; and the teaching content for two classes was the same. The teacher applied multimodal teaching approach to teaching English reading in the experimental class; in contrast, she still adopted the traditional teaching method in the control class.

\subsection{Research instruments}

Questionnaires: Two questionnaires were conducted in this research, one before the experiment and the other after the experiment. The aim of the first questionnaire was to get to know the students' interest in English reading before the experiment and whether they were willing to try a new teaching approach. The second one was to find out the students' willingness to participate in English reading class in the experiment and their attitude towards the multimodal reading teaching.

Tests: Students in this research took two tests. One was pre-experiment test and the other post-experiment test. The pre-experiment test paper was designed by the teacher herself; it was intended to check students' learning outcome during their winter holiday and to get to know whether there was a significant difference in reading comprehension between the two classes. Four reading passages were chosen in the test paper; there were 20 multiple choice questions with 40 points in total. The test was taken on the first Monday of the semester. Post-experiment test paper was structured in the same way as the pre-experiment test. It was used to find out the result of the two-month teaching experiment. SPSS 18 was used to analyze the results of the two tests and make a comparison of the results of the two classes.

\subsection{Research procedures}

The research focused on a teaching experiment which was to prove the effects of multimodal reading teaching in EFL. A reading test and a questionnaire were conducted before the experiment, and another reading test and questionnaire were conducted after the experiment. Then the data were collected for analysis and findings were obtained. The procedures are displayed as Fig. 1.

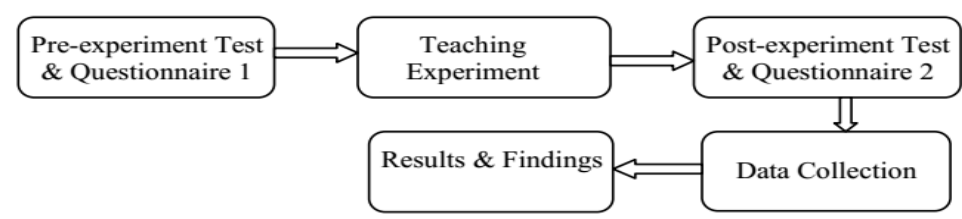

Fig. 1. Research procedures

Pre-experiment phase: The research began at the beginning of March 2019 and ended at the end of April 2019, lasting 2 months. In the first week of March, a reading test and a questionnaire were given to all the students in Class 2 and Class 3 of Grade 2 of Dangshan No. 2 Senior High School. 
The pre-experiment test paper was designed by the teacher herself and taken by two classes at the same time with an aim to find out whether the students of the two classes were equivalent in English reading proficiency. 4 reading passages with 20 multiple choice questions were required to be finished within 40 minutes. The results of test indicated that there was no significant difference in students' average scores between these two classes, so the two classes could be adopted in this experiment. Class 2 was chosen as the experimental class and Class 3 as the control class.

After the test, students were given a questionnaire of eight questions which were asked about their participation in English reading class, their comment on the present teaching method of English reading and their attitude towards trying a new teaching method. There were four choices for each question: A=Strongly Agree, B=Agree, $\mathrm{C}=$ Disagree and $\mathrm{D}=$ Strongly Disagree. The teacher handed out the question sheets in person, and made sure that everyone completed the questionnaire carefully. Altogether 108 copies of the questionnaire were handed out to students and 108 valid answered copies of the questionnaire were recovered.

Experiment phase: The experiment lasted for eight weeks. During this period, the multimodal teaching method was adopted in the experimental class; in contrast, the traditional teaching method was adopted in the control class. The paper takes teaching of "Unit1: Festivals around the World" as an example to illustrate how English reading teaching of the experiment class was carried out. The experiment phase can be further divided into 3 stages, namely, pre-reading stage, while-reading stage and postreading stage. Teaching procedures of the experiment class are demonstrated as follows.

Pre-reading stage

Step 1: The teacher played a Christmas song through PPT and asked students to guess what was going to be taught.

Step 2: The teacher played two video clips successively on PPT. One was about Westerners' celebrating Christmas, the other about Chinese celebrating the Spring Festival (see Fig. 2). Then she asked students to describe and compare the two festivals.
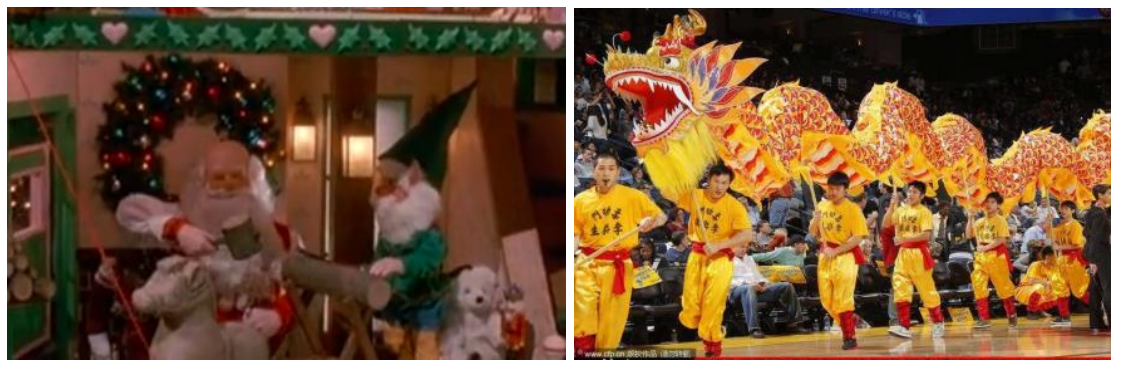

Fig. 2. Westerners' celebrating Christmas and Chinese celebrating the Spring Festival

Step 3: The teacher showed some pictures about some traditional festivals of China on PPT and asked students to name the festival represented by each picture (see Fig. 3). 

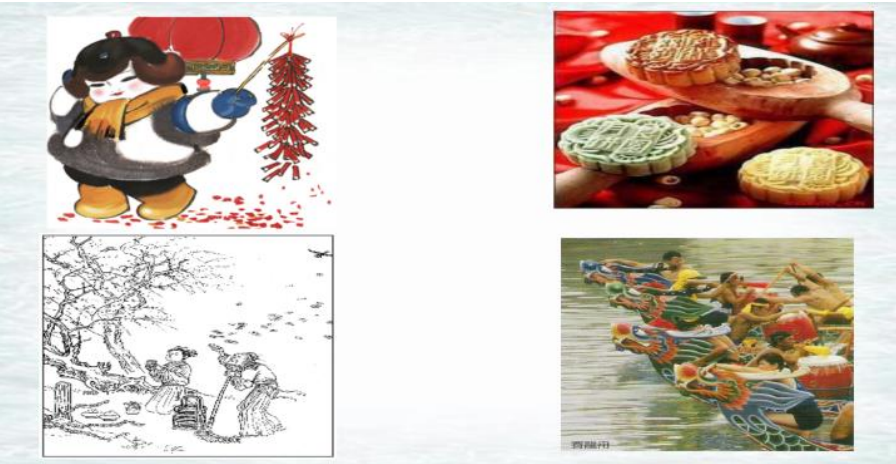

Fig. 3. Pictures of some traditional Chinese festivals

While-reading stage

Step 1: Skimming: The teacher asked students to read the passage and fill in the chart on PPT (see Table 1.).

Table 1. Information of different kinds of festivals

\begin{tabular}{|l|l|l|}
\hline \multicolumn{1}{|c|}{ Kinds of Festivals } & Names of Festivals & \multicolumn{1}{c|}{ Countries } \\
\hline Festivals of the Dead & & \\
\hline Festivals to Honour People & & \\
\hline Harvest Festivals & & \\
\hline Spring Festivals & & \\
\hline
\end{tabular}

Step 2: Scanning: Students read the passage quickly, marked the names of festivals with crayons and finished some true-or-false questions. Fig. 4 was a paragraph taken from the text in which some names of festivals were marked by a student.

\section{Festivals to Honour People}

Festivals can also be held to honour famous people. The Dragon Boat Festival in China honours the famous ancient poet. Qu Yuan. In the USA. Columbus Day is in memory of the arrival of Christopher

25 Columbus in the New World. India has a national fectival on October 2 to honour Mohandas Gandhi, the leader who helped gain India's independence from Britain.

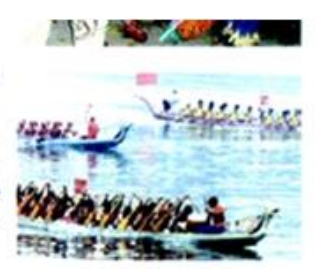

Fig. 4. Festivals to honor people

Step 3: Presentation: The teacher divided students into four groups; students in each group prepared to introduce one festival mentioned in the text. Then each group appointed a representative to introduce the festival they had chosen with PPT and pictures they had collected on the web.

Post-reading stage

Step 1: Students retold the text.

Step 2: Students collected information on their favorite festival, and presented their favorite festival in class with picture, music, video clips and so on. 
Step 3: The teacher drew a mind map of Chinese festivals and a mind map of Western festivals mentioned by students (see. Fig. 5).

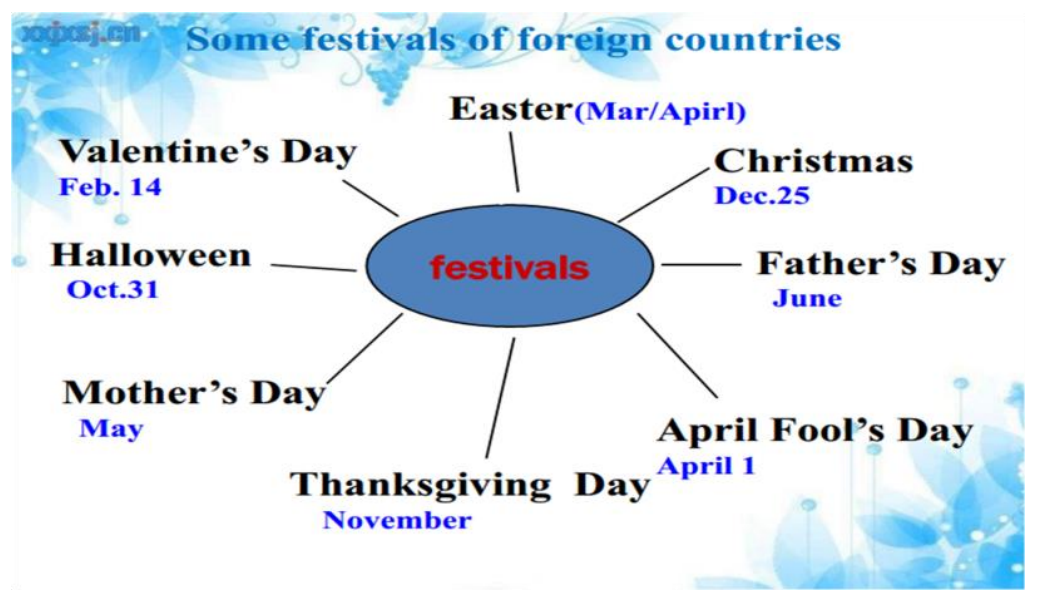

Fig. 5. Mind map of various Western festivals

In experiment class, in pre-reading stage, besides written or spoken language, video clips, pictures and music were employed to stimulate students' different senses so as to arouse their interest in learning and to make them to have an impression of what they were going to learn. In while-reading stage, besides written or spoken language, a chart, crayons, pictures were employed to make students interact in class and have a deep understanding of the passage. In the after-reading stage, besides written or spoken language, pictures, mind maps, music and videos were used to widen students' scope of knowledge of festivals as well as improving their ability to use English language.

As for control class, there was also classroom interaction; but it is very simple and monotonous. The interaction mainly involved question and answer, vocabulary explaining and note-taking. It was difficult to stimulate students' interest in learning, to deepen their understanding, or to widen their scope of knowledge.

Post-experiment phase: After an eight-week teaching experiment, students were given another test-Post-experiment test, the test paper was structured in the same way as the pre-experiment test with 20 multiple choice questions and 40 points in total. It was taken by all students of both experiment class and control class on the last Friday of the April. A comparison analysis of the scores was made between the two classes to find out whether there was a significant difference between them. After the test, students in the experiment class were given another questionnaire. In order to make sure that all the students took the questionnaire seriously, the teacher supervised the process of students' answering questions. Then analysis of the questionnaire was made to find out students' attitude towards multimodal teaching approach and their progress in English reading after the experiment. 


\section{$4 \quad$ Results and Findings}

\subsection{Comparison of students' reading proficiency between EC and CC}

Comparison of students' reading proficiency in pre-experiment test: The preexperiment test was implemented to get to know the difference in students' English reading proficiency between the experiment class (EC) and the control class (CC) before the teaching experiment. Independent sample $\mathrm{T}$ test was employed to analyze the difference based on the scores in the pre-experiment test.

Table 2. Comparison of scores of EC and CC in pre-experiment test

\begin{tabular}{|l|l|c|c|c|c|c|c|}
\hline & Class & $\mathbf{N}$ & $\mathbf{M}$ & SD & MD & T & P \\
\hline \multirow{2}{*}{ English Reading } & EC & 53 & 25.13 & 5.385 & \multirow{2}{*}{.37} & \multirow{2}{*}{.360} & \multirow{2}{*}{.719} \\
\cline { 2 - 6 } & CC & 55 & 24.76 & 5.242 & & & \\
\hline
\end{tabular}

Table 2 showed that the Mean and Std. Deviation in the experiment class were very close to those of control class with only a gap of 0.37 of the mean between the two classes. The table also indicated that $\mathrm{T}=0.360, \mathrm{P}=0.719>0.005$, which suggested that there was no significant difference existing in students' English reading proficiency between the two classes, or reading proficiency of students of both experiment class and control class were almost at the same level. The results could ensure the successful implementation of the experiment.

Comparison of students' reading proficiency in post-experiment test: The postexperiment test was carried out to find out the effect the teaching experiment. The independent samples $\mathrm{T}$ test was employed to analyze the difference in English reading proficiency between the EC and the CC based on the scores in the post-experiment test.

Table 3. Comparison of scores of EC and $\mathrm{CC}$ in post-experiment test

\begin{tabular}{|l|l|c|c|c|c|c|c|}
\hline & Class & $\mathbf{N}$ & $\mathbf{M}$ & SD & MD & T & P \\
\hline \multirow{2}{*}{ English Reading } & EC & 53 & 29.17 & 5.876 & \multirow{2}{*}{3.42} & \multirow{2}{*}{3.158} & \multirow{2}{*}{.002} \\
\cline { 2 - 8 } & CC & 55 & 25.75 & 5.389 & & & \\
\hline
\end{tabular}

Statistics in Table 3 showed that the average score of post-experiment test of experiment class was 29.17, while that of the control class was 25.75 with a gap of 3.42 of the mean between the two classes. Besides, the table indicated that $\mathrm{T}=3.158$, $\mathrm{P}=0.002<0.005$, which suggested that the results of the test had statistical significance. So it could be concluded that there was a significant difference in reading proficiency between the experiment class and control class. In other words, the students in experiment class did better in English reading after the application of multimodal teaching approach compared with students in control class in which the traditional reading teaching method was adopted. . 


\subsection{Students' interest, participation in reading class and their attitude} towards multimodal reading teaching

Results of and major findings of questionnaire (1): Before the experiment, questionnaire (1) was conducted in both the experimental class and the control class, aiming at knowing about students' interest in English reading, their attitude towards present teaching method of English reading and how they thought of trying a new teaching method. Altogether 108 copies of questionnaire were distributed to the experimental class and the control class, and 108 valid answered copies were recovered.

Table 4. Students' interest in and attitude towards English reading before experiment

\begin{tabular}{|l|c|c|c|c|c|c|c|c|}
\hline \multicolumn{1}{|c|}{ Questions } & \multicolumn{2}{c|}{$\begin{array}{c}\text { A Strongly } \\
\text { Agree }\end{array}$} & \multicolumn{2}{c|}{ B Agree } & \multicolumn{2}{c|}{ C Disagree } & \multicolumn{2}{c|}{$\begin{array}{c}\text { D Strongly } \\
\text { Disagree }\end{array}$} \\
\cline { 2 - 10 } & $\boldsymbol{N}$ & $\boldsymbol{P}$ & $\boldsymbol{N}$ & $\boldsymbol{P}$ & $\boldsymbol{N}$ & $\boldsymbol{P}$ & $\boldsymbol{N}$ & $\boldsymbol{P}$ \\
\hline $\begin{array}{l}\text { 1. Do you think English reading plays } \\
\text { an important role in English learning? }\end{array}$ & 59 & $54.6 \%$ & 27 & $25 \%$ & 17 & $15.7 \%$ & 5 & $4.6 \%$ \\
\hline $\begin{array}{l}\text { 2. Are you interested in English } \\
\text { reading? }\end{array}$ & 24 & $22.2 \%$ & 40 & $37 \%$ & 27 & $25 \%$ & 17 & $15.8 \%$ \\
\hline $\begin{array}{l}\text { 3. Do you find English reading class } \\
\text { boring? }\end{array}$ & 39 & $36.1 \%$ & 42 & $38.9 \%$ & 16 & $14.8 \%$ & 11 & $10.2 \%$ \\
\hline $\begin{array}{l}\text { 4. Do you participate actively in } \\
\text { classroom interactions in English } \\
\text { reading class? }\end{array}$ & 17 & $15.7 \%$ & 25 & $17 \%$ & 37 & $34.3 \%$ & 29 & $26.8 \%$ \\
\hline $\begin{array}{l}\text { 5. Are you satisfied with your English } \\
\text { reading ability? }\end{array}$ & 23 & $21.3 \%$ & 28 & $25.9 \%$ & 32 & $29.6 \%$ & 25 & $23.1 \%$ \\
\hline $\begin{array}{l}\text { 6. Are you satisfied with the way your } \\
\text { English teacher is teaching now? }\end{array}$ & 14 & $12.9 \%$ & 23 & $21.3 \%$ & 37 & $34.3 \%$ & 34 & $31.5 \%$ \\
\hline $\begin{array}{l}\text { 7. Do you want your English reading } \\
\text { to be taught in a different way? }\end{array}$ & 47 & $43.5 \%$ & 39 & $36.1 \%$ & 15 & $13.9 \%$ & 7 & $6.5 \%$ \\
\hline $\begin{array}{l}\text { 8. Do you want your teacher to use } \\
\text { multimedia in your English lessons, } \\
\text { such as PPT and video? }\end{array}$ & 53 & $49.1 \%$ & 33 & $30.6 \%$ & 14 & $12.9 \%$ & 8 & $7.4 \%$ \\
\hline
\end{tabular}

From the statistics in Table 4 we can sum up the following findings:

Firstly, most students in these two classes realized the importance of English reading and had interest in English reading. In both experiment class and control class, altogether $79.6 \%$ of the students agreed that English reading played an important role in English learning, 59.2\% of the students were interested in English reading. These made it possible to innovate English reading teaching.

Secondly, the majority of students were not satisfied with the present English teaching, their interest in English reading was not motivated, and they were reluctant to participate in classroom activities. Statistics indicated that $75 \%$ of the students thought that English reading class was very boring, $61.1 \%$ of the students did not think that they participated actively in classroom interaction, $52.7 \%$ of the students were not satisfied with their reading ability, $65.8 \%$ of the students were not satisfied with the way English reading was being taught. All these indicated that it was necessary to reform the present English teaching method. 
Thirdly, students were willing to reform the present mode of teaching and try a new mode of reading teaching. The statistics showed that nearly $80 \%$ of the students wanted their teacher to try a different way of teaching, for example, multimediaassisted English reading teaching.

Results of and major findings of questionnaire (2): Questionnaire (2) was conducted in the experimental class after the experiment, aiming to find out the students' attitude towards the multimodal reading teaching and the effects of the experiment. Altogether 53 copies of questionnaire were handed out to students in experimental class and 53 valid answered copies were recovered.

Table 5. Students' interest in and attitude towards English reading after experiment

\begin{tabular}{|c|c|c|c|c|c|c|c|c|}
\hline \multirow[t]{2}{*}{ Questions } & \multicolumn{2}{|c|}{$\begin{array}{c}\text { A Strongly } \\
\text { Agree }\end{array}$} & \multicolumn{2}{|c|}{ B Agree } & \multicolumn{2}{|c|}{ C Disagree } & \multicolumn{2}{|c|}{$\begin{array}{l}\text { D Strongly } \\
\text { Disagree }\end{array}$} \\
\hline & $N$ & $\boldsymbol{P}$ & $N$ & $P$ & $N$ & $\boldsymbol{P}$ & $N$ & $\boldsymbol{P}$ \\
\hline $\begin{array}{l}\text { 1. Do you think the English reading class is more inter- } \\
\text { esting than before? }\end{array}$ & 65 & $60.2 \%$ & 24 & $22.2 \%$ & 15 & $13.9 \%$ & 4 & $3.7 \%$ \\
\hline $\begin{array}{l}\text { 2. After two months of study, are you more interested in } \\
\text { English reading than before? }\end{array}$ & 63 & $58.3 \%$ & 22 & $20.4 \%$ & 17 & $15.7 \%$ & 6 & $5.6 \%$ \\
\hline 3. Do you like the teacher's new way of teaching? & 56 & $51.9 \%$ & 24 & $22.2 \%$ & 16 & $14.8 \%$ & 12 & $11.1 \%$ \\
\hline $\begin{array}{l}\text { 4. Are you more willing to participate in class activities } \\
\text { after adopting the new teaching approach? }\end{array}$ & 48 & $44.4 \%$ & 35 & $32.4 \%$ & 15 & $13.9 \%$ & 10 & $9.3 \%$ \\
\hline $\begin{array}{l}\text { 5. Are you more active in English classes after the use of } \\
\text { the new teaching method? }\end{array}$ & 45 & $41.7 \%$ & 44 & $40.7 \%$ & 12 & $11.1 \%$ & 7 & $6.5 \%$ \\
\hline $\begin{array}{l}\text { 6. Can you have a better understanding of the passage in } \\
\text { the textbook after adopting the new teaching method? }\end{array}$ & 48 & $44.4 \%$ & 49 & $45.4 \%$ & 8 & $7.4 \%$ & 3 & $2.8 \%$ \\
\hline $\begin{array}{l}\text { 7. Now when you read English articles, can you grasp } \\
\text { the main idea of the article more accurately? }\end{array}$ & 34 & $31.5 \%$ & 37 & $34.3 \%$ & 23 & $21.3 \%$ & 14 & $12.9 \%$ \\
\hline $\begin{array}{l}\text { 8. After adopting the new way of teaching English class, } \\
\text { do you read English faster than before? }\end{array}$ & 27 & $25 \%$ & 39 & $36.1 \%$ & 25 & $23.1 \%$ & 17 & $15.7 \%$ \\
\hline
\end{tabular}

From the statistics in Table 5 we can sum up the following findings:

Firstly, application of multimodal approach stimulated students' interest in English reading. As could be seen from the data in Table 5, after the experiment, in the experimental class, $82.4 \%$ of the students thought English reading class was more interesting than before, $78.7 \%$ of the students were more interested in English reading than before.

Secondly, students took a positive attitude towards multimodal teaching approach, and were more willing to participate in classroom interactions. From the statistics in Table 5, it could be seen that $74.1 \%$ of the students liked the new multimodal teaching method, $75.8 \%$ of the students were more willing to participate in classroom activities because of the new teaching method, $82.4 \%$ of the students admitted that they were more active in English class as a result of multimodal teaching.

Thirdly, application of multimodal teaching approach could help students to understand the reading material better, to grasp the main idea more accurately, and to increase their reading speed. In a word, it could help to develop students reading proficiency. From the statistics in the table, it could also been seen that $89.8 \%$ of the students thought they could understand the reading passage better because of the ap- 
plication of multimodal teaching method, $65.8 \%$ of students believed they could grasp the main idea of the article more accurately, and $61.1 \%$ of students thought they could read English articles faster than before.

\section{$5 \quad$ Discussion and Conclusion}

People communicate with each other through multimodal means. Development of information technology makes it possible to adopt multimodal means in English teaching. Some scholars or educators have put forward some principles and hypotheses of applying multimodal means to English teaching and some teachers have put the principle into practice. Some empirical studies suggested that multimodal English teaching could improve English language teaching efficiency and students' English language proficiency. But the research has been mainly conducted on college English teaching, and very little attention has been given to senior high English reading teaching, especially to teaching reading in EFL in senior high schools in the rural areas in China. In this study an empirical study was conducted to find out the effectiveness of applying multimodal approach to teaching reading in EFL in a rural school in China.

The authors implemented a teaching experiment in which multimodal means like images, colors, mind map, music, video clips, group discussion, and classroom presentation were employed to stimulate students' different senses so as to arouse their interest in English learning and motivate their initiative to participate in classroom interaction. Based on the data collected from questionnaires, pre-experiment test and post-experiment test, the authors reached the following conclusions:

- Application of multimodal teaching approach to English reading teaching could improve students' English reading proficiency. The average score of postexperiment reading test of the experimental class was obviously higher than that of the control class after the teaching experiment; most students in the experiment class believed that they could read an English passage faster, grasp the main idea of the passage more accurately, and understand the passage better because of adoption of multimodal teaching method

- Application of multimodal teaching approach could stimulate students' participation in English reading. A great majority of the students thought that English reading class was more interesting and they were more willing to participate in classroom activities because of the new teaching method.

- Students took a positive attitude towards multimodal teaching approach. About 3/4 of the students in experiment class admitted that they liked the new multimodal teaching method and were more active in English class as a result of multimodal teaching. From the findings of the study, we believe that it is advisable for senior high schools in China rural areas to try to make use of multimodal means to stimulate students' in English reading, motivate their classroom participation, improve their English reading proficiency, and as a result improve English reading teaching result. 
This study was mainly conducted in a rural school in China, and only 53 students from one class were chosen as experiment class subjects, so the results might not be applicable in English reading teaching in all kinds of schools. Different multimodal means may be effective on different occasions, so appropriate use of multimodal means in relevant context is also an important topic which has not been discussed in this thesis. Therefore, in future study research can be carried out in different types of school and more students can be chosen as research subjects, which can produce more convincing results and more constructive suggestions. Besides, how to make good use of multimodal means which are closely related to the teaching content is also a subject to be studied.

\section{References}

[1] Halliday, M. A. K. (1978). Language as social semiotic: the social interpretation of languageand meaning. London: Arnold, $108-126$.

[2] $\mathrm{Hu}$, Zhuanglin. (2007). Multimodalization in social semiotics. Language Teaching and Linguistic Studies. 29(1): 1-10.

[3] Gu, Yueguo. (2007). On multimedia learning and multimodal learning. Technology Enhanced Foreign Language Education, 29(2): 3-13.

[4] Zhu, Yongsheng. (2007). Theory and methodology of multimodal discourse analysis. Foreign Language Research, 30(5): 82-86.

[5] Scollon, R. \& Scollon, S. (2003). Discourse in place: Language in the material world. New York: Routledge.

[6] Barthes, R., \& Heath, S. (1978). Image-music-text. American Journal of Sociology, 5(6), 61-64.

[7] New London Group. (1996). A pedagogy of multiliteracies: Designing social futures. Harvard Educational Review. 66(1), 60-92. https://doi.org/10.17763/haer.66.1.17370n67v22j1 $\underline{60 \mathrm{u}}$

[8] Stein, P. (2000). Rethinking resources multimodal pedagogies in the ESL classroom. TESOL Quarterly, 34( 2), 333-336. https://doi.org/10.2307/3587958

[9] Royce, T. (2002). Multimodality in the TESOL classroom: Exploring visual-verbal synergy. TESOL Quarterly, 36(2): 191-205. https://doi.org/10.2307/3588330

[10] Zhang, Delu. (2009) Application of multimodal discourse analysis and modern media technology to foreign language teaching. Foreign Language Education, 30(04), 15-20.

[11] Sun, Meiwei. Application of multimodal learning in online English teaching. International Journal of Emerging Technologies in Learning, 10(4), 2015: 54-58. https://doi.org/10.39 91/ijet.v10i4.4697

[12] Huang, Wei. (2016). An empirical study of listening English teaching activities in multimodal environment. Foreign Language and Literature, 32(6): 150-156.

[13] Zhang, Wei., Liu, Xiao-bin., \& Zhou, Rong. (2012). An empirical study of multimodality theory-oriented courseware's application in English grammar courseware teaching. Modern Educational Technology, 22(6): 58-61.

[14] Lv, Meijia., \& Mu, Weijiao. (2014). A research on the effect of the multimodal teaching on the college students' reading ability. China Educational Technology, 35(12): 129-132. 


\section{Authors}

Xuequan Pan is an associate professor at Foreign Language School of Huaibei Normal University, Huaibei, 235000, China. His research interests include applied linguistics and discourse analysis. (Email: xuequanpan@126.com)

Zhixin Zhang is from Foreign Language School of Huaibei Normal University, Huaibei, 235000, China, Huaibei, 235000, China, majoring in English education.

Article submitted 2019-07-13. Resubmitted 2019-10-01. Final acceptance 2019-10-05. Final version published as submitted by the authors. 